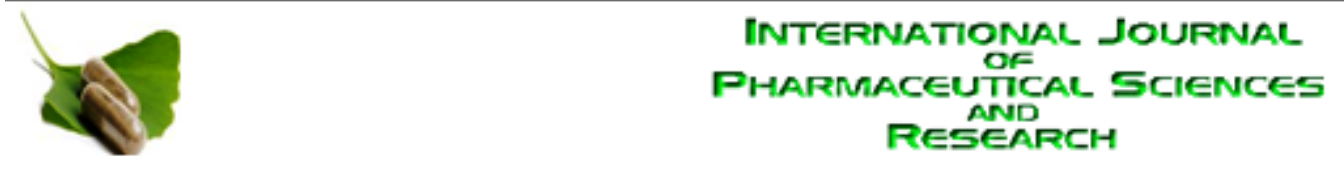

Received on 25 February, 2012; received in revised form 24 April, 2012; accepted 25 June, 2012

\title{
ANTIBACTERIAL ACTIVITY OF SOME SELECTED INDIAN MEDICINAL PLANTS
}

\author{
B. Nitha, A.B. Remashree* and Indira Balachandran \\ Centre for Medicinal Plants Research, Arya Vaidya Sala, Kottakkal, Kerala, India
}

\section{ABSTRACT}

Keywords:

Antimicrobial agent, Infectious disease,

Medicinal Plants,

Multi-drug resistant

Correspondence to Author:

\section{A.B .Remashree}

Deputy Project Director, Drug Standardization Division, Centre for Medicinal Plant Research, Arya Vaidya Sala Kottakkal- 676 503, Kerala, India
There is a continuous and urgent need to discover new antimicrobial compounds with diverse chemical structures and novel mechanisms of action because there has been an alarming increase in the incidence of new and reemerging infectious diseases. In recent years, drug resistance to human pathogenic bacteria has been commonly reported from all over the world. In the present scenario of emergence of multiple drug resistance to human pathogenic organisms, this has necessitated a search for new antimicrobial substances from other sources including plants. In the present study aqueous- ethanol extract of ten plants each belonging to different families was evaluated for antibacterial activity against medically important bacteria viz. S. aureus (MTCC 3160), B. subtilis (MTCC441), E. coli (MTCC40), K. pneumoniae (MTCC3384), P.mirabilis (MTCC425), P.aeruginosa (MTCC741). The in vitro anti-bacterial activity was performed by agar disc diffusion and agar well diffusion method. P. mirabilis was the most resistant bacterium while $S$. aureus was the most susceptible bacteria. Amongst the plant species studied, Terminalia chebula showed best antibacterial activity.
INTRODUCTION: Medicinal plants are part and parcel of human society to combat diseases, from the dawn of civilization ${ }^{1}$. They usually contain many biologically active ingredients and are used primarily for treating mild or chronic ailments. According to World Health Organization (WHO), about $80 \%$ of the world population relies chiefly on the plant based traditional medicine especially for their primary healthcare needs. Herbal medicines are in great demand in the developed as well as developing countries for primary healthcare because of their wide biological and medicinal activities, higher safety margins and lesser costs ${ }^{2,3}$.

Infectious diseases are a major cause of morbidity and mortality worldwide. The number of multi-drug resistant microbial strains and the appearance of strains with reduced susceptibility to antibiotics are continuously increasing. This increase has been attributed to indiscriminate use of broad-spectrum antibiotics, immunosuppressive agents, intravenous catheters, organ transplantation and ongoing epidemics of human immunodeficiency virus (HIV) infections ${ }^{4,5}$. This situation provided the impetus to the search for new antimicrobial substances from various sources like medicinal plants. Synthetic drugs are not only expensive and inadequate for the treatment of diseases but are also often with adulterations and side effects. Therefore, there is a need to search for new infection-fighting strategies to control microbial infections ${ }^{6}$.

Plant medicines are used on a worldwide scale to prevent and treat infectious diseases ${ }^{7}$. Plants are rich in a wide variety of secondary metabolites such as tannins, alkaloids, terpenoids and flavonoids having been found in vitro since they have antimicrobial properties and may serve as an alternative, effective, 
cheap and safe antimicrobial for the treatment of microbial infections ${ }^{8}$. Plant based antimicrobial compounds have great therapeutic potential as they have lesser side effects as compared with synthetic drugs and also little chance of development of resistance. Therefore an attempt has been made to study the antibacterial activity of ten medicinally important plants viz. Artocarpus heterophyllus, Berberis aristata, Chromolaena odorata, Embelia ribes, Jasminum angustifolia, Mahonia leschenaultii, Pluchea lanceolata, Plumbago indica, Terminalia chebula, Vitex negundo.

\section{MATERIALS AND METHODS:}

Plant materials: Fresh plant/ plant parts were collected randomly from Kerala and Tamilnadu region,
India. Some were obtained from the herbal garden (Arya Vaidya Sala, Kottakkal, Kerala, India) and raw drug museum of Centre for Medicinal Plant Research (Arya Vaidya Sala, Kottakkal, Kerala, India). The plants selected for the study include Artocarpus heterophyllus Lam., Berberis aristata DC, Chromolaena odorata L., Embelia ribes Burm.f., Jasmine angustifolia L., Mahonia leschenaultii Wall.ex.wt \& Arn, Pluchea lanceolata DC., Plumbago indica L., Terminalia chebula Retz, Vitex nigundo $\mathrm{L}$. The details of the plant/plant parts were studied - their families, vernacular names and their therapeutic uses are given in Table $1^{9,10,11}$. The plant materials were identified and authenticated and the voucher specimens were deposited in the raw drug museum of Centre for Medicinal Plant Research (CMPR, Arya Vaidya Sala, Kottakkal, Kerala, India).

TABLE 1: ETHNOBOTANICAL INFORMATION ON SOME TRADITIONALLY USED INDIAN MEDICINAL PLANTS SELECTED FOR ANTIBACTERIAL SCREENING

\begin{tabular}{|c|c|c|c|c|}
\hline Plant species & Family & $\begin{array}{c}\text { Common } \\
\text { name }\end{array}$ & Parts used & Therapeutic use \\
\hline $\begin{array}{l}\text { Artocarpus heterophyllus } \\
\text { Lam. }\end{array}$ & Moraceae & Jack fruit tree & $\begin{array}{l}\text { Roots, leaves, } \\
\text { fruits, seeds }\end{array}$ & $\begin{array}{c}\text { Antidiarrhoeal, boil, wound, skin diseases, } \\
\text { dyspepsia, ulcer, convulsions, dyspepsia } \\
\text { ophthalmitis, pharyngitis }\end{array}$ \\
\hline Berberis aristata, DC. & Berberidaceae & $\begin{array}{l}\text { Indian } \\
\text { barberry }\end{array}$ & Root bark & Skin disease, menorrhagia, diarrhoea, jaundice \\
\hline Chromolaena odorata L. & Asteraceae & Eupatorium & Leaf & $\begin{array}{l}\text { Leaf juice used as antiseptic in cuts and } \\
\text { wounds }\end{array}$ \\
\hline Embelia ribes Burm.f. & Myrsinaceae & Embelia & $\begin{array}{l}\text { Fruit, root, } \\
\text { bark }\end{array}$ & $\begin{array}{l}\text { Antihelmintic, diuretic, carminative, } \\
\text { contraceptive dyspepsia, skin diseases, piles, } \\
\text { leprosy, pruritis. }\end{array}$ \\
\hline Jasminum angustifolia L. & Oleacea & Wild jasmine & Leaf, root & $\begin{array}{l}\text { Poison, herpes, ophthalmology, leprosy, } \\
\text { pruritis, wounds, ring worm. }\end{array}$ \\
\hline $\begin{array}{l}\text { Mahonia leschenaultii } \\
\text { Wall.ex.wt \& Arn. }\end{array}$ & Berberidaceae & Mahonia & Root & Diuretic, demulcent \\
\hline Pluchea lanceolata, DC. & Asteraceae & Rasna & Stem, root & $\begin{array}{c}\text { Thermogenic, carminative, rheumatic } \\
\text { disorders, nervous diseases, anorexia, cough, } \\
\text { asthma, bronchitis. }\end{array}$ \\
\hline Plumbago indica L. & Plumbaginaceae & Fire plant & Root & $\begin{array}{l}\text { Leprosy, oedema. Piles, worm infestation, } \\
\text { anaemia, anorexia, fever, bronchial asthma, } \\
\text { leucoderma, diabetes. }\end{array}$ \\
\hline Terminalia chebula, Retz. & Combretaceae & $\begin{array}{c}\text { Black } \\
\text { myrobalan }\end{array}$ & Fruit & $\begin{array}{l}\text { Promote digestive power, heals wounds and } \\
\text { ulcers, skin \&eye disease, diabetes, chronic \& } \\
\text { recurrent fever, anaemia, cardiac disorders, } \\
\text { diarrhoea, spleen enlargement, piles. }\end{array}$ \\
\hline Vitex negundo L. & Verbenaceae & Chaste tree & Leaf, root & $\begin{array}{c}\text { Nervous \& eye, ear diseases, cough, intestinal } \\
\text { worms, rheumatoid arthritis, leprosy, wounds, } \\
\text { oedema, bronchial asthma }\end{array}$ \\
\hline
\end{tabular}


Preparation of Extract: The plant parts were washed thoroughly, dried under shade and powdered. The powdered material (100 g) was extracted with 50\% aqueous-ethanol using water bath- shaker at $40^{\circ} \mathrm{C}$ for $72 \mathrm{~h}$. After 72 hours, the supernatant was filtered and the solvent completely evaporated using vacuum. The residue obtained was stored at $4^{0} \mathrm{C}$ for further studies.

Bacterial cultures: Bacterial cultures were obtained from Microbial Type Culure Collection, Chandigarh, India. The microorganims used for the present study include Staphylococcus aureus (MTCC 3160), Bacillus subtilis (MTCC441), Escherichia coli (MTCC40), Klebsiella pneumonia (MTCC3384), Pseudomonas aeruginosa (MTCC741), Proteus mirabilis, (MTCC425). All the bacterial cultures were maintained in nutrient agar and stored at $4{ }^{\circ} \mathrm{C}$.

Preparation of inocula: Several colonies were transferred to sterile peptone water $(5 \mathrm{ml})$ from the sub cultured organism. The suspensions were mixed for 15 seconds to ensure homogeneity and subsequently diluted to match the turbidity of a 0.5 McFarland standard (i.e. OD $=0.12-0.15$ at $\mathrm{k}=530 \mathrm{~nm}$, corresponding to $1-5 \times 106 \mathrm{CFU} / \mathrm{ml}$ ).

The antimicrobial assay was performed by two methods viz. agar disc diffusion method 12 and agar well diffusion method 13. Mueller Hinton agar (MHA) was prepared in plates as the media for test bacteria. The bacterial inoculum was spread evenly on the surface of the MHA plates using a sterilized cotton swab. For agar disc diffusion method, sterile filter paper discs $(6 \mathrm{~mm})$ were saturated with different concentrations of the test compound, allowed to dry and introduced on the upper layer of the seeded agar plate.

For agar well diffusion method, a well was prepared in the plates with the help of a cork-borer $(0.6 \mathrm{~cm}) .100 \mu \mathrm{l}$ of the test compound was introduced into the well. The plates were incubated overnight at $37^{\circ} \mathrm{C}$ For each bacterial strain controls were maintained where pure solvents were used instead of the extract. Sterile distilled water served as negative control. The result was obtained by measuring the zone diameter. The experiment was done thrice and the mean values are presented.
The results were compared with the standard antibiotics nitrofurantoin $(300 \mathrm{mg} / \mathrm{disc})$, chloramphenicol (30mg/disc), cephalxein $(30 \mathrm{mg} / \mathrm{disc})$ and gentamicin (10 mg/disc).

RESULTS AND DISCUSSION: Antibiotic resistance has become a global concern ${ }^{14}$. There has been an increasing incidence of multiple resistances in human pathogenic microorganisms in recent years, largely due to indiscriminate use of commercial antimicrobial drugs commonly employed in the treatment of infectious diseases. This has forced scientists to search for new antimicrobial substances from various sources like the medicinal plants.

Nature has been a source of medicinal agents since times immemorial. Plants have provided a source of inspiration for novel drug compounds as plant derived medicines have made significant contribution towards human health. Furthermore, the active components of herbal remedies have the advantage of being combined with many other substances that appear to be inactive. However, these complementary components give the plant as a whole a safety and efficiency much superior to that of its isolated and pure active components 15,16 . The presence of antibacterial substances in the higher plants is well established ${ }^{17}$.

The study reveals the profound antimicrobial activity of aqueous-ethanol extract of ten different plant species. Table $\mathbf{2}$ and $\mathbf{3}$ shows the results of antibacterial potential of different plant extracts. All the tested extracts showed varying degrees of strain specific inhibitory action. Among the plants screened, Terminalia chebula exhibited maximum growth inhibitory activity and Mahonia leschenaultii exhibited minimum growth inhibitory activity towards the tested strains. In disc diffusion method the higher dose of $M$. leschenaultii extract $(100 \mu \mathrm{g})$ inhibited the growth of B.subtilis with a zone mean diameter of $12 \mathrm{~mm}$.

In well diffusion method the extract inhibited the growth of B.subtilis, E.coli and K.pneumoniae with a zone diameter 15, 13 and 14 respectively. Proteus mirabilis is found to be the least sensitive organism, which only showed sensitivity towards Embelia ribes, Jasminum angustifolia, Terminalia chebula and Vitex negundo. 
TABLE 2: ANTIMICROBIAL ACTIVITY OF AQUEOUS- ETHANOL EXTRACT OF SCREENED MEDICINAL PLANTS - DISC DIFFUSION METHOD

\begin{tabular}{|c|c|c|c|c|c|c|c|c|c|c|c|c|c|c|c|c|c|c|c|c|c|c|c|c|}
\hline \multirow{3}{*}{ Plants } & \multicolumn{24}{|c|}{ Zone of Inhibition (mm) } \\
\hline & \multicolumn{4}{|c|}{$\begin{array}{l}\text { S. aureus } \\
\text { MTCC } 3160\end{array}$} & \multicolumn{4}{|c|}{$\begin{array}{l}\text { B. subitilis } \\
\text { MTCC } 441\end{array}$} & \multicolumn{4}{|c|}{$\begin{array}{c}\text { E. Coli } \\
\text { MTCC40 }\end{array}$} & \multicolumn{4}{|c|}{$\begin{array}{l}\text { K. pneumonae } \\
\text { MTCс } 3384\end{array}$} & \multicolumn{4}{|c|}{$\begin{array}{l}\text { P. mirabilis } \\
\text { MTCC } 425\end{array}$} & \multicolumn{4}{|c|}{$\begin{array}{l}\text { P. aeruginosa } \\
\text { MTCC } 741\end{array}$} \\
\hline & 20 & 40 & 80 & 100 & 20 & 40 & 80 & 100 & 20 & 40 & 80 & 100 & 20 & 40 & 80 & 100 & 20 & 40 & 80 & 100 & 20 & 40 & 80 & 100 \\
\hline $\begin{array}{l}\text { Artocarpus } \\
\text { heteropyllus }\end{array}$ & 8 & 10 & 13 & 16 & - & - & - & - & - & - & - & - & 7 & 10 & 11 & 12 & - & - & - & - & 17 & 20 & 21 & 22 \\
\hline $\begin{array}{l}\text { Berberis } \\
\text { aristata }\end{array}$ & 19 & 28 & 29 & 30 & 6 & 9 & 12 & 13 & 7 & 13 & 15 & 19 & - & 11 & 12 & 13 & - & - & - & - & - & 14 & 16 & 17 \\
\hline $\begin{array}{c}\text { Chromolaen } \\
\text { a orderata }\end{array}$ & 12 & 20 & 21 & 23 & 11 & 15 & 16 & 18 & 5 & 6 & 6 & 7 & - & - & - & 10 & - & - & - & - & - & 5 & 6 & 7 \\
\hline $\begin{array}{c}\text { Embelia } \\
\text { ribes }\end{array}$ & 7 & 10 & 14 & 17 & - & - & - & - & 8 & 10 & 13 & 15 & 9 & 11 & 15 & 18 & 5 & 9 & 10 & 11 & 6 & 8 & 12 & 15 \\
\hline $\begin{array}{c}\text { Jasminum } \\
\text { angustifolia }\end{array}$ & 28 & 33 & 34 & 36 & 7 & 9 & 13 & 20 & - & - & 10 & 15 & - & - & 7 & 13 & 9 & 10 & 13 & 16 & - & - & - & - \\
\hline $\begin{array}{c}\text { Mahonia } \\
\text { leschenaultii }\end{array}$ & - & - & - & - & - & - & 10 & 12 & - & - & - & - & - & - & - & - & - & - & - & - & - & - & - & - \\
\hline $\begin{array}{c}\text { Pluchea } \\
\text { Ianceolata }\end{array}$ & 10 & 13 & 16 & 19 & - & - & - & - & 9 & 13 & 14 & 17 & 9 & 11 & 13 & 17 & - & - & - & - & 9 & 10 & 13 & 16 \\
\hline $\begin{array}{c}\text { Plumbago } \\
\text { indica }\end{array}$ & 9 & 14 & 17 & 20 & - & - & - & - & 9 & 10 & 11 & 13 & 7 & 10 & 12 & 13 & - & - & - & - & 7 & 8 & 12 & 13 \\
\hline $\begin{array}{c}\text { Terminalia } \\
\text { chebula }\end{array}$ & 20 & 22 & 24 & 26 & 15 & 17 & 22 & 25 & 20 & 25 & 28 & 30 & 10 & 11 & 13 & 15 & 13 & 16 & 20 & 21 & 11 & 15 & 18 & 20 \\
\hline $\begin{array}{c}\text { Vitex } \\
\text { negundo }\end{array}$ & 11 & 14 & 16 & 20 & - & - & - & - & - & - & - & - & - & 15 & 18 & 20 & 9 & 13 & 14 & 16 & - & 14 & 18 & 20 \\
\hline
\end{tabular}

TABLE 3: ANTIMICROBIAL ACTIVITY OF AQUEOUS- ETHANOL EXTRACT OF SCREENED MEDICINAL PLANTS - WELL DIFFUSION METHOD

\begin{tabular}{|c|c|c|c|c|c|c|c|c|c|c|c|c|c|c|c|c|c|c|c|c|c|c|c|c|}
\hline \multirow{3}{*}{ Plants } & \multicolumn{24}{|c|}{ Zone of Inhibition (mm) } \\
\hline & \multicolumn{4}{|c|}{$\begin{array}{l}\text { S. aureus } \\
\text { MTCC } 3160\end{array}$} & \multicolumn{4}{|c|}{$\begin{array}{l}\text { B. subitilis } \\
\text { MTCC } 441\end{array}$} & \multicolumn{4}{|c|}{$\begin{array}{c}\text { E. Coli } \\
\text { MTCC40 }\end{array}$} & \multicolumn{4}{|c|}{$\begin{array}{l}\text { K. pneumonae } \\
\text { MTCC3384 }\end{array}$} & \multicolumn{4}{|c|}{$\begin{array}{l}\text { P.mirabilis } \\
\text { MTCC } 425\end{array}$} & \multicolumn{4}{|c|}{$\begin{array}{l}\text { P.aeruginosa } \\
\text { MTCC 741 }\end{array}$} \\
\hline & 20 & 40 & 80 & 100 & 20 & 40 & 80 & 100 & 20 & 40 & 80 & 100 & 20 & 40 & 80 & 100 & 20 & 40 & 80 & 100 & 20 & 40 & 80 & 100 \\
\hline $\begin{array}{c}\text { Artocarpus } \\
\text { heteropyllus }\end{array}$ & 10 & 12 & 15 & 17 & - & - & - & - & - & - & - & - & 6 & 12 & 15 & 18 & - & - & - & 10 & 15 & 19 & 22 & 25 \\
\hline $\begin{array}{l}\text { Berberis } \\
\text { aristata }\end{array}$ & 16 & 19 & 24 & 26 & - & - & 10 & 12 & - & - & 11 & 12 & - & - & - & 13 & - & - & - & - & - & - & - & - \\
\hline $\begin{array}{c}\text { Chromolaen } \\
\text { a orderata }\end{array}$ & 14 & 16 & 20 & 22 & 12 & 15 & 17 & 20 & 8 & 10 & 12 & 15 & - & 10 & 15 & 19 & - & - & - & - & - & 8 & 8 & 10 \\
\hline $\begin{array}{c}\text { Embelia } \\
\text { ribes }\end{array}$ & 12 & 14 & 18 & 20 & - & - & - & - & 10 & 13 & 16 & 20 & 10 & 12 & 16 & 20 & 6 & 12 & 14 & 16 & 9 & 11 & 13 & 15 \\
\hline $\begin{array}{c}\text { Jasminum } \\
\text { angustifolia }\end{array}$ & 30 & 32 & 34 & 38 & 8 & 10 & 12 & 18 & - & 10 & 14 & 16 & - & - & 9 & 17 & 8 & 12 & 15 & 18 & - & - & - & - \\
\hline $\begin{array}{c}\text { Mahonia } \\
\text { leschenaultii }\end{array}$ & - & - & - & - & 7 & 10 & 13 & 15 & - & - & 11 & 13 & - & 10 & 12 & 14 & - & - & - & - & - & - & - & - \\
\hline $\begin{array}{c}\text { Pluchea } \\
\text { Ianceolata }\end{array}$ & 18 & 22 & 23 & 26 & - & - & - & - & 10 & 17 & 20 & 23 & 12 & 14 & 23 & 25 & - & - & - & - & 10 & 12 & 15 & 19 \\
\hline $\begin{array}{c}\text { Plumbago } \\
\text { indica }\end{array}$ & 15 & 18 & 23 & 24 & - & - & - & - & 9 & 10 & 12 & 13 & 10 & 13 & 14 & 15 & - & - & - & - & 9 & 10 & 12 & 14 \\
\hline $\begin{array}{l}\text { Terminalia } \\
\text { chebula }\end{array}$ & 20 & 22 & 24 & 26 & 15 & 17 & 22 & 25 & 20 & 25 & 28 & 30 & 10 & 11 & 13 & 15 & 13 & 16 & 20 & 21 & 11 & 15 & 18 & 20 \\
\hline $\begin{array}{c}\text { Vitex } \\
\text { negundo }\end{array}$ & 13 & 15 & 18 & 22 & - & - & - & - & - & - & - & - & - & 19 & 23 & 23 & 10 & 13 & 17 & 18 & 10 & 14 & 20 & 24 \\
\hline
\end{tabular}

Among these four extracts, P.mirabilis showed maximum sensitivity towards T.chebula with a zone diameter of 21 for disc diffusion and 24 for well diffusion at a concentration of $100 \mu \mathrm{g}$ of the extract.
S.aureus is found to be the most susceptible organism to all the tested extracts except $M$. leschenaultii. In both methods maximum zone of growth inhibition against S.aureus was shown by Jasminum angustifolia 
and the zone diameter was found to be 36 for disc diffusion $(100 \mu \mathrm{g})$ and 38 for well diffusion method (300 $\mu \mathrm{g})$.

Various researchers have shown that Gram positive bacteria are more susceptible towards plant extracts as compared to Gram negative bacteria ${ }^{18,19}$. These differences may be attributed to fact that the cell wall in Gram positive bacteria is of a single layer, whereas the Gram negative cell wall is multilayered structure ${ }^{20}$.

The antibacterial activity of the plant extracts studied was compared with standard antibiotics. The zone of growth inhibition formed by the standard antibiotics was given in Table 4. The results signify that most of the plant extracts possess more growth inhibitory activity than the standard antibiotics against all the tested organisms except for P.mirabilis. The growth of P.mirabilis is significantly inhibited by all the standard antibiotics tested.

\section{TABLE 4: ANTIBACTERIAL ACTIVITY OF STANDARD ANTIBIOTICS}

\begin{tabular}{ccccc}
\hline \multirow{2}{*}{ Bacterial strains } & \multicolumn{4}{c}{ Zone of Inhibition $(\mathbf{m m})$} \\
\cline { 2 - 5 } & FU & CP & CK & GM \\
\hline S. aureus & 10 & $\mathrm{R}$ & 35 & 15 \\
B. Subitilis & 12 & $\mathrm{R}$ & 20 & 13 \\
E. coli & 14 & $\mathrm{R}$ & $\mathrm{R}$ & 8 \\
K. pneumoniae & 9 & $\mathrm{R}$ & 14 & 9 \\
P.mirabilis & 22 & 25 & 21 & 20 \\
P.aeruginosa & $\mathrm{R}$ & $\mathrm{R}$ & $\mathrm{R}$ & $\mathrm{R}$ \\
\hline
\end{tabular}

FU: Nitrofurantoin (300mg), CK: Chloramphenicol (30mg), CP: Cephalexin (30mg), GM: Gentamicin (10 mg)

The study thus reveals the effectiveness of the tested plant extracts against some pathogenic bacteria commonly associated with various human infections. They can be used as potential source for the development of a phytomedicine to act against infectious bacteria. The antimicrobial activities can be enhanced if the phytoactive components are purified and adequate dosage determined for proper administration. As the global scenario is now changing towards the use of non toxic plant products having traditional medicinal use, development of modern drugs from plants should be emphasized for the control of infectious diseases.

\section{REFERENCES:}

1. Chaudhary G, Goyal S, Poonia P. Lawsonia inermis Linnaeus: A Phytopharmacological Review. International Journal of Pharmaceutical Sciences and Drug Research 2010; 2(2): 91-98.

2. Goyal BR, Goyal RK, Mehta AA. Phyto-Pharmacognosy of Archyranthes aspera: A Review. Pharmacognosy Reviews 2008; 1:1.

3. Cragg GM, Newman DJ, Sander KM. Natural products in drug discovery and development. Journal of Natual Products 1997; 60:52-60.

4. Dean DA, Burchard KW. Fungal infection in surgical patients. American Journal of Surgery 1996; 171: 374-382.

5. Gonzalez CE, Venzon D, Lee $S$ et al. Risk factors for fungemia in children infected with human immunodeficiency virus: a case control study. Clinical Infectious Diseases 1996; 23: 515-521,

6. VaghasiyaY, Chanda SV Screening of Methanol and Acetone Extracts of Fourteen Indian Medicinal Plants for Antimicrobial Activity. Turkish Journal of Biology 2007; 31:243-248.

7. Soulsby EJ. Resistance to antimicrobials in humans and animals. Britsh Journal of Medicine 2005; 331: 1219-1220.

8. Cowan MM. Plant products as antimicrobial agents. Clinical Microbiology Reviews 1999; 12: 564-82.

9. Udayan PS, Balachandran I: Medicinal Plants of Arya Vaidya Sala Herb Garden. Department of Publication Arya Vaidya Sala, Firt Edition 2009.

10. Kirtikar KR and Basu BD. Indian Medicinal Plants. Inernational Book Ditributers, Dehra Dun, Editin 2, Vol 1, 2005: 102-103.

11. The Wealth of India. A Dictionary of Indian raw materials and industrial products, Publication and Information Directorate, Council of Scientific and Industrial Research, New Delhi, Vol 4, 1962: 225-226.

12. Bauer AW, Kirby WMM, Sherris JC, Turck M. Antibiotic susceptibility testing by a standardized single disk method. American Journal of Clinical Pathology 1966; 45: 493-496.

13. Perez C, Paul M, Bazerque P. An Antibiotic assay by the agar well diffusion method. ActaBio Medica Exp 1990; 15: 113-115.

14. Westh H, Zinn CS, Rosdahl VT, Sarisa Study Group. An international multicenter study of antimicrobial consumption and resistance in $\mathrm{S}$. aureus isolates from 15 hospitals in 14 countries. Microbial Drug Resistance. 2004. 10:169 -176

15. Shariff ZU. Modern Herbal Therapy for Common Ailments. Nature Pharamcy Series. Spectrum Books Ltd., Ibadan, Nigeria in Association with Safari Books (Export) Ltd. UK, Vol.1,2001: 9-84

16. Parekh J and Chanda S Antibacterial and phytochemical studies on twelve species of Indian medicinal plants. African Journal of Biomedical Research 2007; 10: 175 - 181

17. Srinivasan D, Nathan S, Suresh T, Perumalaswamy O. Antimicrobial activity of certain Indian Medicinal Plants used in folkloric medicine. Journal of Ethnopharmocology 2001; 74: 217-220.

18. Lin J, Opoku AR, Geheeb-Keller M Hutching AD, Terblanche SE, Jagar AK, van Staden J. Preliminary screening of some traditional zulu medicinal plants for anti-inflammatory and antimicrobial activities. Journal of Ethnopharmacology 1999; 68:267-274.

19. Parekh J and Chanda S. In vitro antimicrobial activities of extract of Launnaea procumbent Rob. (Labiateae), Vitis vinifera (Vitaceae) and Cyperus rotundus (Cyperaceae). African Journal of Biomedican Research 2006; 9:89-93.

20. Yao J and Moellering R. Antibacterial agents. Manual of Clinical Microbiology.ASM Wahington DC, 1995: 1281-1290.

How to cite this article:

Nitha B., Remashree A.B. and Balachandran I: Antibacterial Activity of Some Selected Indian Medicinal Plants. Int J Pharm Sci Res, 2012; Vol. 3(7): 2038-2042. 